Data Communications and Transmission Principles An Introduction 


\section{Other Macmillan titles of related interest}

B. Allen, Analogue Electronics for Higher Studies

W.A. Atherton, From Compass to Computer

M. Beasley, Reliability for Engineers

P.V. Brennan, Phase-Locked Loops - Principles and Practice

C.W. Davidson, Transmission Lines for Communications, second edition

M.E. Goodge, Analog Electronics

B.A. Gregory, An Introduction to Electrical Instrumentation and Measurement Systems, second edition

Robin Holland, Microcomputer Fault-finding and Design, second edition

Paul A. Lynn, An Introduction to the Analysis and Processing of Signals, third edition

R.J. Mitchell, Microprocessor Systems - An Introduction

Noel M. Morris, Electrical Circuit Analysis and Design

M.S. Nixon, Introductory Digital Design

R.C. Seals and G.F. Whapshott, Programmable Logic: PLDs and FPGAs

P. Silvester, Electric Circuits

T.J. Terrell and Lik-Kwan Shark, Digital Signal Processing

M.J. Usher and C.G. Guy, Information and Communication for Engineers

M.J. Usher and D.A. Keating, Sensors and Transducers, second edition

L.A.A. Warnes, Electronic Materials

B.W. Williams, Power Electronics - Devices, Drivers, Applications and Passive Components, second edition

\section{Macmillan New Electronics Series}

G.J. Awcock and R. Thomas, Applied Image Processing

Rodney F.W. Coates, Underwater Acoustic Systems

M.D. Edwards, Automatic Logic Synthesis Techniques for Digital Systems

Peter J. Fish, Electronic Noise and Low Noise Design

W. Forsythe and R.M. Goodall, Digital Control

C.G. Guy, Data Communications for Engineers

Paul A. Lynn, Digital Signals, Processors and Noise

Paul A. Lynn, Radar Systems

R.C.V. Macario, Cellular Radio - Principles and Design

A.F. Murray and H.M. Reekie, Integrated Circuit Design

F.J. Owens, Signal Processing of Speech

Dennis N. Pim, Television and Teletext

M. Richharia, Satellite Communications Systems - Design Principles

P. Shepherd, Integrated Circuit Design, Fabrication and Test

M.J.N. Sibley, Optical Communications, second edition

P.M. Taylor, Robotic Control

G.S. Virk, Digital Computer Control Systems 


\title{
Data Communications and Transmission Principles
}

\author{
An Introduction
}

\author{
Andrew Simmonds \\ School of Engineering \\ Sheffield Hallam University
}


(C) A. J. Simmonds, 1997

All rights reserved. No reproduction, copy or transmission of this publication may be made without written permission.

No paragraph of this publication may be reproduced, copied or transmitted save with written permission or in accordance with the provisions of the Copyright, Designs and Patents Act 1988, or under the terms of any licence permitting limited copying issued by the Copyright Licensing Agency, 90 Tottenham Court Road, London W1P 9HE.

Any person who does any unauthorised act in relation to this publication may be liable to criminal prosecution and civil claims for damages.

The author has asserted his rights to be identified as the author of this work in accordance with the Copyright, Designs and Patents Act 1988.

First published 1997 by MACMILLAN PRESS LTD

Houndmills, Basingstoke, Hampshire RG21 6XS

and London

Companies and representatives

throughout the world

ISBN 978-0-333-64689-2

DOI 10.1007/978-1-349-13900-2

ISBN 978-1-349-13900-2 (eBook)

A catalogue record for this book is available from the British Library.

This book is printed on paper suitable for recycling and made from fully managed and sustained forest sources.

$\begin{array}{rrrrrrrrrr}10 & 9 & 8 & 7 & 6 & 5 & 4 & 3 & 2 & 1 \\ 06 & 05 & 04 & 03 & 02 & 01 & 00 & 99 & 98 & 97\end{array}$




\section{Contents}

Preface

ix

PART I Basic Data Communication

1 Basic Concepts

1.1 Communications and information 1

1.1.1 Bits, bytes and nibbles $\quad 4$

1.1.2 Character codes $\quad 6$

1.1.3 Coding for efficient transmission $\quad 7$

$\begin{array}{lr}\text { 1.1.4 Parity } & 10\end{array}$

$\begin{array}{ll}1.2 \text { Information theory } & 12\end{array}$

$\begin{array}{ll}\text { 1.2.1 Huffman coding } & 15\end{array}$

$\begin{array}{ll}1.2 .2 \text { Fax machines } & 18\end{array}$

2 Signal Characteristics 21

2.1 Square wave as sum of sinusoids $\quad 23$

2.2 Fourier series 26

2.2.1 Related transforms 29

2.3 Introduction to filters 30

2.3.1 The communication channel 32

2.3.2 First order low pass filter $\quad 34$

2.3.3 First order high pass filter $\quad 36$

2.3.4 Higher order filters $\quad 37$

2.3.5 Delay and phase characteristics $\quad 38$

2.3.6 Rise-time bandwidth product $\quad 40$

3 Data Communication over an Analogue Telephone Channel 46

3.1 Serial interfaces 46

3.1.1 The RS-232 standard 47

3.1.2 RS-232 data interchange $\quad 50$

3.1.3 Null modems $\quad 54$

3.1.4 Other standard interfaces $\quad 55$

3.2 Asynchronous protocol 57

3.2.1 Asynchronous data format $\quad 59$

3.2.2 Error correction using echoplexing $\quad 60$

3.2.3 IBM-PC serial interface 61

$\begin{array}{ll}3.3 \text { Modems } & 62\end{array}$

3.3.1 Modulation techniques 63

3.3.2 Modulation techniques compared $\quad 65$ 
$\begin{array}{ll}\text { 3.3.3 Multi-state signalling } & 67\end{array}$

$\begin{array}{ll}\text { 3.3.4 Modem standards } & 71\end{array}$

3.3.5 Modem options and facilities $\quad 72$

3.3.6 Trellis Coded Modulation 75

$\begin{array}{lr}\text { PART II Transmission Principles } & 81\end{array}$

4 Transmission Lines $\quad 81$

4.1 Copper links $\quad 81$

$\begin{array}{lll}4.1 .1 & \text { Twisted pair } & 81\end{array}$

4.1.2 Coaxial cable $\quad 83$

4.2 Basic transmission line theory $\quad 84$

$\begin{array}{ll}\text { 4.2.1 Characteristic impedance } & 87\end{array}$

4.2.2 Lossless line $\quad 90$

4.2.3 Distortionless line 91

4.2.4 Propagation coefficient $\quad 94$

4.3 Reflections $\quad 98$

$\begin{array}{lr}\text { 4.3.1 PCB layout } & 106\end{array}$

5 Propagation 111

5.1 Electromagnetic spectrum and light $\quad 111$

$\begin{array}{ll}5.2 \text { Radio waves } & 116\end{array}$

$\begin{array}{ll}\text { 5.2.1 Ionospheric propagation } & 117\end{array}$

$\begin{array}{ll}5.2 .2 \text { Ground wave propagation } & 119\end{array}$

$\begin{array}{lr}\text { 5.2.3 Line of sight propagation } & 120\end{array}$

$\begin{array}{ll}5.2 .4 \text { Ducting } & 121\end{array}$

$\begin{array}{lll}5.3 \text { Antennas } & 121\end{array}$

5.4 Microwaves 124

$\begin{array}{ll}\text { 5.4.1 Free-space path loss } & 127\end{array}$

$\begin{array}{ll}5.4 .2 \text { Link budget } & 128\end{array}$

6 Fibre Optics $\quad 132$

6.1 Snell's law $\quad 136$

6.2 Total internal reflection $\quad 138$

$\begin{array}{ll}6.3 \text { Dispersion } & 139\end{array}$

$\begin{array}{lr}6.4 \text { Step index fibre } & 140\end{array}$

6.4.1 Modal dispersion 141

6.4.2 Acceptance angle $\quad 143$

$\begin{array}{ll}6.5 \text { Graded index fibre } & 144\end{array}$

$\begin{array}{ll}\text { 6.6 Monomode fibre } & 146\end{array}$

$\begin{array}{ll}\text { 6.7 Cable characteristics } & 147\end{array}$

$\begin{array}{ll}6.8 \text { System considerations } & 148\end{array}$ 
7 Data Link Protocols 153

7.1 Character oriented protocols $\quad 155$

7.1.1 Bisync 156

$\begin{array}{ll}\text { 7.1.2 IBM } 3270 \text { master/slave protocol } & 157\end{array}$

7.1.3 Basic Mode 158

$\begin{array}{ll}7.2 \text { HDLC } & 159\end{array}$

7.2.1 HDLC control byte $\quad 160$

7.2.2 Supervisory commands 163

7.2.3 HDLC conclusion 164

7.3 Error detection and correction $\quad 165$

7.3.1 Hamming single bit code 167

7.3.2 Cyclic Redundancy Check 169

$\begin{array}{ll}7.4 \text { Link utilization } & 172\end{array}$

8 Wide Area Networks and Open Standards 179

8.1 Seven layer reference model 181

$\begin{array}{lll}8.2 X .25 & 185\end{array}$

8.2.1 X.25 protocol $\quad 185$

$\begin{array}{ll}\text { 8.2.2 PAD } & 187\end{array}$

$\begin{array}{ll}8.2 .3 \text { X.25 summary } & 189\end{array}$

$\begin{array}{lll}8.3 \mathrm{TCP} / \mathrm{IP} & 190\end{array}$

8.3.1 TCP/IP application layer services $\quad 192$

8.3.2 IP addressing 194

8.3.3 Comparison of the seven layer RM and TCP/IP 198

8.3.4 TCP and IP protocol headers 199

$\begin{array}{ll}\text { 8.3.5 Routing } & 201\end{array}$

8.4 Circuit switching 205

9 Local Area Networks $\quad 211$

9.1 LAN topologies 211

9.2 LAN standards 213

9.3 Logical Link Control protocol 214

9.4 Ethernet 215

9.4.1 Ethernet physical layer $\quad 217$

9.4.2 10BaseT 220

9.5 Token Ring $\quad 222$

9.5.1 Token Ring MAC protocol 223

9.6 Ethernet and Token Ring compared 226

9.7 High speed LANs $\quad 227$

$\begin{array}{ll}\text { 9.7.1 FDDI } & 227\end{array}$

9.8 Bridges 230

9.8.1 Spanning Tree Algorithm bridges 231 
9.8.2 Source routing bridges 235

9.8. STA and source routing compared 235

10 Fast Packet Switching $\quad 238$

$\begin{array}{ll}10.1 \text { Congestion } & 238\end{array}$

$\begin{array}{ll}10.2 \text { Frame relay } & 239\end{array}$

10.3 ATM 241

$\begin{array}{ll}\text { 10.3.1 Physical layer } & 243\end{array}$

$\begin{array}{ll}\text { 10.3.2 ATM layer } & 243\end{array}$

10.3.3 ATM Adaption Layer (AAL) 246

$\begin{array}{ll}\text { 10.3.4 ATM conclusion } & 247\end{array}$

$\begin{array}{ll}10.4 \text { ATM and LAN emulation } & 248\end{array}$

$\begin{array}{ll}10.5 \text { DQDB } & 249\end{array}$

$\begin{array}{ll}\text { 10.5.1 Physical layer } & 250\end{array}$

$\begin{array}{ll}\text { 10.5.2 MAC layer } & 252\end{array}$

$\begin{array}{ll}10.6 \text { Conclusion } & 254\end{array}$

Appendix A: Greek alphabet $\quad 257$

Appendix B: units $\quad 258$

$\begin{array}{lr}\text { Appendix C: decibel } & 261\end{array}$

Appendix D: ASCII code table 265

$\begin{array}{ll}\text { Answers } & 267\end{array}$

$\begin{array}{ll}\text { References } & 282\end{array}$

$\begin{array}{ll}\text { Glossary } & 286\end{array}$

$\begin{array}{ll}\text { Index } & 303\end{array}$ 


\section{Preface}

Data communications can be a 'dry' subject. To help make it relevant and more interesting this book highlights significant applications of data communications, explains the use of familiar equipment (e.g. the IBM PC), and gives ideas for readers to do some investigating themselves. The theory in this book is explained in terms of the operation of standard communications equipment or protocols. This serves two purposes: firstly to gain an appreciation of the technology; and secondly to develop a necessary degree of familiarity with the standards and jargon. There is an extensive glossary at the back to help with this jargon.

The main aim of communication is to enable people to obtain information, so, although this is a technical subject, it is bound up with how people organize themselves in society, for example, in setting standards or controlling markets. The achievements of individuals and interactions with society are therefore mentioned in passing to set the subject in context.

Each chapter concludes with a number of questions to help readers to test their understanding, with answers provided at the back of the book.

\section{Intended readership}

This book is written for students on an undergraduate degree or HND course, studying a unit on data communications, communications engineering, information engineering, or similar. A minimum amount of prior knowledge is needed for the early chapters, whilst later chapters build naturally on the work covered in earlier chapters. The book is based on lectures given over a period of some years to different courses (including short courses for industry); hence much of the material covered has been successfully field tested! However, in producing this book the opportunity was taken to expand on the material covered in the lectures. The aim in doing this is to make the book more useful than a collection of lecture notes, allowing students to gain a deeper understanding of a particular topic where they have the time and interest. The book is suitable for self-study, with an extensive glossary and a set of questions and answers on each chapter.

As anyone involved in the subject knows only too well, data communications is going through a period of rapid change. The fundamentals, however, remain constant and some of the older technologies stubbornly refuse to die. The aim of the book is to enable students to build their own framework of data communication concepts, into which they can fit their own existing (and future) knowledge and experiences. 
Although the book is intended primarily for electrical engineering students, it is also suitable for many students of computer studies who need to understand the technological base of the communications industry and how it will determine the future shape of that industry.

\section{Plan of the text}

I shall not write at length on this, as a good overview of the material and level can be gained by looking at the contents. Briefly then, the book is divided into three main parts:

- Part I - Basic Data Communications (chapters 1-3). This deals with definitions and basic signal characteristics, as well as covering modem links in detail as a means of introducing ideas on interfaces, protocols, and standards. This enables work to be discussed with reference to practical communications equipment.

- Part II - Transmission Principles (chapters 4-6). This covers transmission lines, free space links and fibre optics. The emphasis here is on how these topics are interrelated, although each is treated separately so that it is possible to cover the topics in isolation.

- Part III - Protocols and Networks (chapters 7-10). Chapter 7 introduces this part by considering synchronous protocols for point-to-point links, especially the bit oriented protocol HDLC. Wide Area Networks (WANs) are then covered, which allows the OSI seven layer reference model to be introduced whilst explaining X.25. TCP/IP is also covered, which leads on to a comparison of open standards. Local Area Networks (LANs) such as Ethernet and Token Ring are then dealt with. Finally, new network protocols and ideas are discussed in the last chapter.

\section{Acknowledgements}

Above all I would like to thank the students that I have taught, as I have learned with them and sometimes from them. I am very grateful to those colleagues and friends who reviewed chapters from the book and gave their comments and advice - in particular Bill Barraclough, John Colan, Steve Ferguson, Fary Ghassemlooy, Ian Halliday, Bob Harris, John Holding, John Rowe and Colin Smythe. I would also like to thank and acknowledge the work of my publisher's reviewers, amongst them Steve Bate and Deshinder Singh Gill. Thanks also to my publisher Malcolm Stewart, for his encouragement and advice, and to Nicky Gladwin for her typing. 
The impetus for writing this book came from the development of a videobased learning package on Data Communications [MAD]. I worked with Richard Madin and Richard Gibson on that project and would especially like to thank them for their ideas and help; indeed Richard Madin is co-author of chapters 1 and 3. Richard has gone on to produce some Computer Aided Learning packages on data communications [CAL]. Although this book has been written as a stand-alone text-book, it is divided into much the same topic areas as the CAL material and can be used as a back-up text.

Finally, my grateful thanks to my wife Roma, for her help and encouragement.

Andrew Simmonds

August 1996

School of Engineering Sheffield Hallam University

Pond Street

Sheffield S1 1WB

UK

E-mail: A.Simmonds@SHU.AC.UK 